\title{
19 PROTECTING THE DEAD: THE SOUTH AFRICAN NATIONAL HERITAGE RESOURCES ACT IN CONTEXT
}

\section{Dineo Skosana ${ }^{1}$}

\section{INTRODUCTION}

Although grave relocations are a common phenomenon in contemporary South Africa, not much has been written to reflect on the laws that administer heritage resources and graves. This chapter provides an overview of the development of the South African National Heritage Resources Act No. 25 of 1999 (NHRA). It ultimately considers how this legislation regulates the resting place of certain remains after death. An analysis of the historical background of this Act, illuminates the democratic government's pressure to incorporate all forms of heritage that were previously marginalised by colonial typologies of heritage. The attempt to reform South Africa's heritage resulted in broad yet, undetailed legislative provisions of what constitutes heritage, what is to be protected and how. It is this ambiguity in the legislation, this chapter argues, that the laws governing graves are inadequate to address. ${ }^{2}$ When exploited, the existing loopholes, as well as insufficient implementation, violate the cultural constitutional rights of the previously marginalised communities.

To fully comprehend the provisions of the NHRA, how it regulates graves and the limitations of this Act, this chapter first draws attention to the history of law in South Africa. It considers the degree of influence of European legal traditions, as well as the religious basis of Roman and Roman-Dutch legal systems, and ultimately examines how these shaped the regulation of heritage resources - in particular, graves. The chapter concludes that the external legal influence that has its basis in Christian values, and the need to adhere to progressive international legislative standards, constructs a fallacy that South Africa's heritage act is the most progressive in Africa. Scholars suggest that the Act is progressive because it is broad, inclusive and represents a diverse South African nation, when in reality, the legislation does not sufficiently provide for intangible heritage and indigenous beliefs. This, in turn, permits the disturbance of graves from land with contested ownership rights, and also

1 Department of Political Studies, The University of the Witwatersrand and The Wits History Workshop.

2 This argument is also articulated by Esterhuysen A and Saccaggi B. 2014. "Sekuruwe Grave Relocation: A Lesson in Process and Practice", The South African Archaeological Bulletin 69(200):173-181, who both point to the flaws in the legislation that protects heritage resources and graves in South Africa, and weaknesses in the way that these legislated processes are implemented. 
undermines the cultural rights of the previously disadvantaged communities which are endorsed by the Constitution of the Republic of South Africa, 1996.

\section{EXTERNAL INFLUENCE ON THE SOUTH AFRICAN LEGAL TRADITIONS}

Much the same as other South African laws, which are a product of interwoven but distinct legal traditions, the laws that regulate heritage and graves in South Africa, are no exception. The foundation of these laws can be found in the early codified Roman law, Roman-Dutch law and English common law, whose provisions have been followed and sometimes betrayed by the South African legislation. South African law scholars, Robert Hahlo and Ellison Kahn, as well as, legal theorist Hosten, ${ }^{3}$ share the view that the South African common law has its foundational roots drawn from the earlier Roman law and RomanDutch $^{4}$ law. That being said, these scholars align with Melbourne Univerisity legal studies scholar, Martin Chanock whose view is that South African law was also constructed internally as a response to local circumstances and the needs of the developing state, economy and ruling classes. ${ }^{5}$

Roman-Dutch law was introduced at the Cape of Good Hope (present day Cape Town) by Dutch settlers in the middle of the seventeenth century. ${ }^{6}$ Before then, Netherlands mainly applied a Germanic common law, but also versions of a modified Roman law. ${ }^{7}$ South African English-common law coalesced with Roman-Dutch law in the aftermath of Britain's occupation of the Cape in $1806 .{ }^{8}$ Chanock details the preservation of Roman-Dutch law and its combination with English law when he explains that, "[a]fter the Union, the creation of RomanDutch canon was carried on by the Appellate Division which rolled back the advances that English common-law doctrines had made, particularly in Natal. Paradoxically, however, because judges were the primary agents, they saved the Roman-Dutch law by English common-law methods, case by case." ${ }^{9}$ As a result, a mixed jurisdiction that typifies modern South African law developed. ${ }^{10}$ Over the years, the influence of English law has been most marked amongst

3 See details in Hahlo R and Kahn E. 1968. The South African Legal System. Cape Town: Juta; Hosten WJ. 1983. Introduction to South African Law and Legal Theory. Durban: Butterworths.

4 See Du Toit F. 2014. "Roman-Dutch law in modern South African succession law", Ars Aequi, April:278, who defines Roman-Dutch law as "a legal system developed in the Netherlands through the reception particularly in the sixteen and seventeenth centuries of Roman law and its synthesis with Germanic customary law, feudal law and canon law".

5 Chanock M. 2001. The Making of South African Legal Culture 1902-1936. Cambridge: Cambridge University Press, 155.

6 Du Toit, "Roman-Dutch law", 278.

7 Hahlo and Kahn, The South African Legal System, 516.

8 Du Toit, "Roman-Dutch law", 278.

9 Ibid, 159.

10 Ibid, 279. 
other bodies of law in criminal procedure, civil procedure, evidence and constitutional law. ${ }^{11}$ Laws relating to private property and succession preserved their Roman-Dutch character. Of particular interest for consideration of the issue of grave relocation is the remnant influence and application of RomanDutch law of ownership and property in contemporary legislation.

\section{THE RELIGIOUS BASIS OF ROMAN LAW}

Ancient Rome had no principle analogous to "separation of church and state". ${ }^{12}$ For this reason, the same men who were elected public officials could also serve as the highest ranking priests. ${ }^{13}$ Central to Roman religious law was the idea of the immortality of the soul, and this served as the basis for the deification of Roman emperors as incarnations of divinity before and after life. ${ }^{14}$ Beliefs about resurrection, exaltation and the idea that the head of state is the son of God had a long history. ${ }^{15}$ Religious associations with gods would be halted when Christianity became a lawful religion under Constantine's Roman Empire. Before then, however, Christianity was considered blasphemous and persecution was an official policy tended towards Christian and religious beliefs that were considered pagan. After the ascendancy of the first Christian Emperor Constantine to power, laws were passed that prevented the persecution of Christians. ${ }^{16}$ Thereafter, cathedrals were rapidly built all over the Roman Empire. Tracing the progression of canon law in Rome, the Roman law scholar, Charles Sherman records in the year 315 CE that Constantine empowered his subjects to bequeath their property to the Church. ${ }^{17}$ So freely and frequently was this permission subsequently acted upon, that half a century later, Christian churches and religious orders were found to own vast quantities of property.

The adoption of Christianity gave rise to the formation of congregations with many varying opinions about the Christian doctrine and no centralised way of enforcing orthodoxy..$^{18}$ However, a set of guidelines meant to define Christian beliefs and differentiate them from heretical doctrines was proposed after the First Council of Nicaea. ${ }^{19}$ Fundamental to the Roman Nicene Creed (a core statement of Christian belief) was the idea of the "Trinity", which refers to the teaching that there is one God who comprises three distinct aspects, the "Father"

11 Hahlo and Kahn, The South African Legal System, 19.

12 Rüpke J. 2007. A Companion to Roman Religion. London: Blackwell, 4.

13 Members of the elite classes held priesthood.

14 Thomson A. 2008. Bodies of thought: science, religion, and the soul in the early Enlightenment. Oxford: Oxford University Press, 42.

15 Haasbroek D. 1995. The Mythology and Political Origins of Christianity. Cape Town: V \& R Printing Works.

16 Kelly C. 2006. The Roman Empire: A Very Short Introduction. New York: Oxford University Press.

17 Sherman C. 1919. "Brief History of Imperial Roman Canon Law", California Law Review 7:93, 94.

18 Rodney S. 1996. The Rise of Christianity. Princeton: Princeton University Press.

19 Morgan J. 2003. Constantine Ruler of Christian Rome. New York: Rosen Central. 
(God), "the Son" (Jesus Christ, God's earthly incarnation) and the "Holy Spirit", sometimes referred to as the "Holy Ghost") as the maker of heaven and earth. ${ }^{20}$ Equally important to this belief is that through the death and resurrection of Jesus Christ, sinful humans can be reconciled to God and thereby offered salvation and the promise of eternal life. ${ }^{21}$

A brief analysis of the religious basis of Roman law illustrates the dominance and influence of Roman political and religious philosophies, which spread across Europe during different historical periods. Not only was this political influence transmitted to European territories through Roman invasion such as the Netherlands, but also passed on to African colonies in the modern age. Fundamental to this chapter is the relationship between state law and religion. The association between the latter and the former was and continues to be one of the primary debates within political theory..$^{22}$ In a contemporary edited series, titled Law and Religion, editor Gad Barzilai suggests that "modern law and religion are complementary, contradictory and simultaneous sources of rulemaking, adjudication and execution. Both embed obedience and obligations, leadership, institutions and legal ideology as foundations of their maintenance and prevalence, based on a strict structure of commands." ${ }^{23}$ Considering the historic influence of widespread Christian values on legal systems and on burial laws, to be precise - it is evident that modern legislation, particularly in postcolonial South Africa, neglects beliefs on ancestors and the customary practices related to these. The Heritage Act is broadly framed with the objective of restorative justice, however, its provisions do not thoroughly consider the relationship that African communities have with the dead. The effect of this is evident from a case study of Glencore colliery mine's relocation of ancestral graves that belong to former labour tenants and migrant laborers from the Tweefontein farm, in the Mpumalanga province of South Africa in 2013. ${ }^{24}$

20 See for details the Holy Bible: Genesis 1 refers to the Father, verse 2 the Spirit, and verse 3 the Son.

21 See the Holy Bible, John 2:25.

22 The earlier works of Niccolò Machiavelli and John Locke amongst others shaped modern debates on the relationship between state, politics, law and religion.

23 Gad B (ed). 2007. "Law and Religion", in The International Library of Essays in Law and Society. Aldershot: Ashgate, xi.

24 Although the case study is central to the ideas and the argument in this chapter, it only reflects on the Heritage Act and its inadequacies which allows the disturbance of graves. The case study was selected to understand why grave relocations are subject to contestations. Phenomenological interviews were conducted with fourteen families whose ancestral graves were relocated. The study found amongst other areas of contestations, that grave relocations are disputed because ancestors are not simply bearers of good and bad omen (spiritual security), but also symbolise the families' history of migration and settlement. Their graves are evidence in South Africa's post-apartheid land restitution programme, while the general sentiment was that Glencore managers (who argue that the graves are on their property), treated the families' remains like objects that stand in the way of production and profit making. Although a wake-fee (compensation fee) of R1,500 was offered to the families, this was not negotiated and not regulated 
South African law has in some respects conformed, yet at times disregarded, the laws of the Romans who held much respect for graves. Old sources reveal the Romans' use of the words grave and tomb interchangeably. Occasionally, a clear distinction between the latter and the former was made. A grave was defined as the space occupied by the deceased..$^{25}$ Graves, in this regard, were classified as things of religious law that were dedicated to gods of lower regions res religiosae. ${ }^{26}$ Under Roman law, corporeal objects, ${ }^{27}$ were classified into those which are subject to ownership res commercio and those not susceptible to ownership res extra commercium. ${ }^{28}$ Graves were unsusceptible to ownership, and as such, they were inalienable. Analysing the categories of religion and commerce in Roman law, Algerian born historian of French law, Yan Thomas writes that "neither the places reserved for the dead nor the monuments erected above them were heritable or marketable. They could not be sold." ${ }^{29}$ That being said, the sculptures of a grave were alienable. ${ }^{30}$ Grave violation was measured on the basis of the principle which states that only that part of the soil in which the deceased was actually buried could benefit from prohibition against profanation, and only this particular part was excluded from the market. ${ }^{31}$ Usually, however, violation consisted of an alteration to the monument, which was defined as anything built above the religious place, including the tomb itself and the air above it, according to the principle that ownership of the ground carried with it ownership of the upper levels. ${ }^{32}$ Elaborating on the laws on grave violation Yan Thomas records that Roman law envisaged the harming of the dead only indirectly through the violation of their tomb. From this perspective, to exhume the body without the state's consent was to put the tomb itself to death. ${ }^{33}$

by the Heritage Act. Thus, the families could not afford to perform rituals such as slaughtering, and the gathering of relatives for an official ceremony to inform their ancestors about the relocations. This has left families in a state of spiritual insecurity, in which they think their ancestors will not approve of the process of the relocations and might in turn create social instability for the living.

25 Ulpian, de sepulchre violato in Thomas Y. 2004. "Res religiosae: on the categories of religion and commerce in Roman law", in Pottage A and Mundy M (eds). Law, Anthropology, and the Constitution of the Social: Making Persons and Things. Cambridge: Cambridge, University Press, 44 records that "the place accorded to the tomb is not religious in its entirety, but only to the extent that a body is inhumed within it. A tomb without the remains was considered as a monument."

26 Thomas Y. "Res religiosae", 40-72.

27 Jonkers J. 2005. The Silence of the Dead: Ethical and Juridical Significances of the Exhumations at Prestwich place, Cape Town, 2003-2005, MPhil Thesis, University of Cape Town, 77.

28 Lawsa 27 (first reissue), 211-212.

29 Thomas, "Res religiosae",' 41.

30 Ibid.

31 Ulpian, de supulchro violato, in Thomas, "Res religiosae", 44.

32 Thomas, "Res religiosae", 57.

33 Ibid, 63-66. 
Violation laws were concerned with that which constitutes a tomb - for to empty a tomb of its contents was to extinguish the res religiosae. ${ }^{34}$

Similarly, Dutch jurist Johannes Voet commonly referred to by South African courts, accepted that the bones themselves were sacred but a cenotaph - an empty tomb erected to those buried elsewhere, or whose bodies are missing - was not. ${ }^{35}$ Additionally, burying in the property of another person without consent did not make a place consecrated. However, this did not mean that the landowner might exhume the bones without the permission of the governor. This was because, "the very removal of the bones embraced in itself something of a religious nature" according to the commentaries. ${ }^{36}$

Voet's view, however, differed from that of earlier Dutch practitioners when he suggested that religious things such as graves could be alienated for a just cause; and could be sold together with land, that is, as an accessory to the sale of something larger. This was on condition that the "thing continued to be used for its sacred purpose" ${ }^{37}$ Simultaneously, there were Roman-Dutch commentators who differed on whether the Roman res religiosae was still recognised by the law of Holland. ${ }^{38}$ In an attempt to narrow these contested views, the seventeenthcentury Dutch jurist Hugo Grotius wrote that:

In relation to man, many writers have distinguished things as belonging to God (res divini juris) and belonging to men (res humani juris); and under things belonging to God the Romans included dedicated things (res sacrae), the graves of the dead (res religiosae) and the walls of the cities (res sanctae): but upon a careful examination it will be found that all these things belong to men. ${ }^{39}$

In this regard, because graves were the private property of individuals, they were subject to commerce. Graveyards on private property formed part of the land; they were not inalienable because of their religious nature. As such, graves belonged to the landowner. ${ }^{40}$ This change of religious doctrine, Neville Cloete, who writes the history of the South African judicial system explains, was an outcome of the Reformation that had made itself felt in Holland in the mid16th century, with "religious freedom" being declared in $1572 .{ }^{41}$ With the public practice of Roman Catholicism banned in Holland in 1580, the Roman Church had lost its authority and all things fell under worldly political authority. ${ }^{42}$ Yet

34 Thomas, "Res religiosae", 64.

35 Voet Commentaries, xi 72.

36 Voet Commentaries, xi 73.

37 Voet Commentaries, xi 86.

38 See for more details in Jonkers, The Silence of the Dead, 77.

39 Grotius H. 1926. The Jurisprudence of Holland, Oxford: Clarendon Press in Jonkers, The Silence of the Dead, 83.

40 Lawsa 27(1), note 383.

41 Cloete N. 1987. "Res religiosae en die stigtingsfiguur - 'n historiese ondersoek na die juridiese aard en konstitusie van die sogenaamde religieuse sake in die SuidAfrikaanse reg", Transkei Law Journal, 136.

Ibid. 
paradoxically, the violation of a tomb sepulchri violatio was still recognised as wrongful by Roman-Dutch law. ${ }^{43}$

Both Roman law and Roman-Dutch law recognised the sacredness of graves and made provisions to protect them accordingly. Most significant to this chapter is that both legal traditions in some way favoured the landowner. The latter could not exhume a grave without a permit, however, he or she could obtain authorisation from the governor. Noteworthy, are remnants of both legal traditions in contemporary legislations in South Africa. Grave exhumation without a permit remains prohibited. And similarly, in the aforementioned case study, Glencore is in possession of the title deed of the sites that are mined. The mine's land tenure, coupled by a mining permit, gives developers more leverage over communities whose graves are subject to relocations.

\section{FROM THE BUSHMAN RELICS PROTECTION ACT OF 1911 TO THE NATIONAL MONUMENTS ACT OF 1969}

By the twentieth century, various cases concerning burial sites which came before the South African courts would illustrate an allegiance to the modified Roman-Dutch law, under which land with the presence of graves could be bought and sold. However, under Roman law the prohibition of desecration of graves and exhumation of remains without authorisation remained in force. ${ }^{44}$ This meant that the purpose of graves would have to be retained even after alienation of the land on which they might be situated. Although, the University of Cape Town private law scholar, Julian Jonkers, explains that in then Union of South Africa ${ }^{45}$ it was not always a statutory offence to violate a grave. The first such general legislation appeared in the Transvaal in $1925 .{ }^{46}$ The Transvaal Ordinance has since been assigned to the Province of Gauteng, ${ }^{47}$ Northern Province, ${ }^{48}$ North-West Province ${ }^{49}$ and the Mpumalanga. ${ }^{50}$ Early Natal Ordinances have been consolidated as the KwaZulu-Natal Cemeteries and Crematoria Act 12 of $1996 . .^{51}$ In the Cape, the first such legislation dates back to $1980 .^{52}$

43 De Vos Wouter. 1952. "Grafskending", South African Law Journal 296:298-299.

44 See details of the cases in Jonkers, The Silence of the Dead, 86-90.

45 Predecessor to the Republic of South Africa.

46 See Jonkers, The Silence of the Dead and the Removal of Graves and Dead Bodies Ordinance 7 of 1925 (Province Transvaal) which prohibited the destruction or removal of graves without consent from authorities.

47 Proclamation 114 of 17 June 1994.

48 Proclamation 109 of 17 June 1994.

49 Proclamation 110 of 16 June 1994.

50 Proclamation 112 of 16 June 1994.

51 The provisions on exhumation and reinternment apply throughout the province, as opposed to for example the provisions on cemeteries, which apply in specified areas of the province. Section 2.

52 Exhumation Ordinance 12 of 1980 which now applies to the Eastern, Northern and Western Cape under different proclamations. 
Prior to the Union of South Africa, there had not been any formal legislation that regulated cultural heritage..$^{53}$ The first heritage agency was organised in 1905 , as a result of activism opposing the demolition of a castle in the Cape for new railroads. ${ }^{54}$ The earliest statute to regulate heritage, the Bushman Relics Protection Act, was enacted in 1911. This Act sought to protect aboriginal paintings and sites of archaeological and anthropological interest, including burial grounds and skeletal remains, as well as other relics. ${ }^{55}$ The BushmanRelics Protection Act would initiate a series of laws, such as the Natural and Historical Monuments Act 6 of 1923, as well as the Relics and Antiques Act of 1934 (which consolidated the Bushman-Relics Protection Act). These were later followed by the National Monuments Act of 1969. Considering the later heritage legislation, South Africa's heritage specialist Delmont suggests that, this string of legislation was designed to bolster the state ideology of Afrikaner Nationalism and separate development. ${ }^{56}$

As far as burial sites were concerned, the National Monuments Act of 1969 protected the "anthropological or archaeological contents of the graves" used by Bushmen or any other people who inhabited or visited South Africa before the settlement of Europeans at the Cape, alongside other Bushman relics and artefacts. It was an offence under the Act to destroy, damage, excavate, alter, remove, from the original site or export from the South Africa such objects without a permit. ${ }^{57}$ Removal of such objects could only take place without felony if found during a normal course of mining, engineering or agricultural activities. However, anything found would have to be immediately reported to a cultural institution by the finder or the owner of the land. ${ }^{58}$ In common law, such found objects were regarded as res nullius, and ownership would vest in the finder. ${ }^{59}$

The National Monuments Act protected war graves only after it was amended in $1981 .{ }^{60}$ Previously, war graves had been covered by separate statutes. The 1981 National Monuments Amendment Act repealed the War Graves Act and included the provisions relating to war graves under the National Monuments

53 Richings F. “Historical Monuments, Wrecks and War Graves”, Lawsa 10(2) (first reissue).

54 See this in Saccaggi B. 2011. Disenfranchised Heritage, Ancestral Graves and Their Legal Protection in South Africa, MA Thesis, University of the Witwatersrand, 31, where he points out that that the role of the National Society was to protect colonial relics, as these were considered a vital aspect of the country's genesis. Precolonial structures and objects were given little consideration, with the main focus on imperial heritage.

55 Bushman Relics Protection Act 22, 1911.

56 Delmont E. 2004. "South African heritage development in the first decade of democracy", African Arts 34(4):39-94.

57 National Monuments Act 1969, Section 12 (2A).

58 National Monuments Act 1969, Section 12 (2A).

59 Section 12(3)(B). A permit system for excavations was added in 1935, and in 1969 permits became necessary for collecting artefacts and fossils as well.

60 National Monuments Act 13, 1981. 
Act, which then became known as the War Graves and National Monuments Act. University of Cape Town scholar of engineering and the built environment, Stephen Townsend, records that there were eleven acts at the time and amendments on the subjects of monuments and war graves between 1967 and $1981 .^{61}$ This flurry of legislative activity, according to him, "demonstrates the apartheid's pre-occupation with heritage and its management in this period after South Africa's expulsion from the United Nations and the Commonwealth and its deepening isolation". ${ }^{62}$

This was not the end of statutory protection. The Commonwealth War Graves Act was enacted in 1992 to protect graves of members of the armed forces who died during World War I and World War II. ${ }^{63}$ But it is the National Heritage Resources Act of 1999 (NHRA), the most recent heritage legislation, having commenced operation on April 2000, that will occupy the rest of this discussion. Although the Act is relevant in its entirety, only its general aims and specific provisions regarding burials places will be discussed.

\section{TOWARDS THE NATIONAL HERITAGE RESOURCES ACT}

The restorative justice "master narrative", 64 was dominant during the constitutional negotiations of 1992-1993, leading to the 1994 elections. ${ }^{65}$ This narrative saw the birth of negotiations over reparations for human rights abuses, which led to various programmes such as the Truth and Reconciliation Commission (TRC) and Restitution of Land Rights in 1995.

The very language of loss and restoration was fundamental in the construction of the National Heritage Resources Act of 1999. The NHRA was written in line with the Constitution of the Republic of South Africa, 1996, which states in Chapter 2 of the Bill of Rights that individuals have rights to belong to cultural groups and participate in cultural life. Subsequent sections provide that persons may not be denied their right to enjoy their culture, practise their religion, use their language and join related associations. Considering the background within which the South African Constitution was written, it would seem that the idea

61 Townsend S. 2003. Development rights and conservation constraints. Urban conservationsoriented controls in the city centre of Cape Town, DPhil Diss, University of Cape Town.

62 Ibid, 62.

63 Act 8 of 1992. The Commonwealth War Graves Act 8 of 1992 prohibits the desecration, damage and destruction of graves, tombstones, monuments and memorials connected with the burials of members of the commonwealth armed forces who died in the First and Second World War (s 1 and 2). The owner of land upon which such a grave is situated, nor any other body in control of the burial place, may disinter or alter the grave, unless three months' notice were given to the commission (s 3(1)). The grave may not be removed except by the commission or with the written permission of the commission (s 3(4)).

64 This notion is borrowed from the work by Walker C. 2008. Land Marked: Land Claims and Land Restitution in South Africa. Athens, OH: The University Ohio Press, 34 .

65 Ibid, 35. 
to encourage individuals to practice their religion is premised on the notion that South Africans are diverse citizens with wide-ranging religious beliefs. Nonetheless, the reality is that the previous and current heritage legislations reflect an endorsement of Christian values, in that they overlook indigenous beliefs in ancestors (intangible heritage). ${ }^{66}$

In its preamble, the NHRA states that "heritage has the potential to affirm our diverse cultures, and in so doing shape our national character" ${ }^{\prime \prime}$ In essence, being a nation and the process of becoming a nation could only be realised if diverse cultural resources were protected and managed by the state in order to promote the nation's well-being. Describing the context under which the NHRA was adopted, Delmont observes that "the program of nation-building that underlies the Act was not without its problems". Drawing from the work of anthropologists John and Jean Comaroff, she suggests that there were obvious anomalies in the formation of modern nation-states in an era of globalisation. South Africa affirmed its sense of national identity at a moment in which currencies were amalgamating, borders were becoming more permeable, trade and industry barriers were being reduced and the global economic landscape was being marked by the logos of the multinational corporations ${ }^{68}$ Therefore matters of development, job creation and poverty alleviation would surpass those around preservation as far as mining and grave relocations are concerned in South Africa.

Janette Deacon, a member of the Arts and Culture Task Group (ACTAG), records that by 1994 out of the 4000 national monuments no less than $98 \%$ represented colonial and settler history, with the remainder comprising natural heritage geological, paleontological, archaeological and rock art sites. ${ }^{69}$ South African heritage specialist Penny Pistorius explains that the need for better definitions of heritage and the mechanisms of its protection brought about a number of amendments to the National Monuments Act, which was finally repealed in 1999, by the new National Heritage Resources Act..$^{70}$ The NHRA was a product of recommendations submitted by the ACTAG, set up by the Minister of Arts and Culture. ACTAG produced two reports that detailed recommendations on arts, culture, as well as heritage policy. As a basis for that, the Department of Arts and Culture put together a white paper in 1996 and adopted principles proposed by the ACTAG. Once the white paper had been published, a public participation process ensued and a draft heritage

66 Beliefs such as the treatment of remains (that are symbolic of ancestors) with respect, as well as performing traditional rituals and ceremonies to appease the ancestors.

67 Ibid, (preamble).

68 Delmont E. 2004. “Re-Environing Greater Johannesburg: South African Heritage Development in the first Decade of Democracy", African Arts 37(4).

69 Deacon H, Mngqolo S and Prosalendis S. 2003. "Protecting Our Cultural Capital: A research plan for the Heritage Sector". HSRC Working paper.

70 Pistorius P. 1996. "Legislation and the National Monuments Act", in ICOMOS. Monuments and Sites South Africa. Sri Lanka: ICOMOS. 
bill was developed. Then a member of ACTAG, Janette Deacon recollects that Penny Pistorius, an independent contractor and former National Monuments Council's employee, whose responsibility was to draft the bill, went through other countries' heritage legislations. Australia, New Zealand, Canada, and to some degree the U.K. heritage legislations were the most influential. The Burra Charter $^{71}$ principles adopted to create a national and international accepted standard for heritage conservation in Australia, were very influential in drafting the NHRA, according to Janette Deacon.

\section{PROVISIONS OF THE SOUTH AFRICAN NATIONAL HERITAGE RESOURCES ACT}

The influence of international definitions and typologies of heritage is very evident on the NHRA. Most international definitions generally continue to equate heritage with built structures, artefacts, or objects from the past. Thus, the material aspect has been paramount in defining heritage. Tangible heritage is defined as "a monument, group of buildings or site of historical, aesthetic, archaeological, scientific, ethnological or anthropological value". ${ }^{72}$ This definition, as incorporated into laws, reflects the perception that for heritage to be valued, it had to be ancient. Accordingly, places of significance and objects or items have been equated with monuments, relics or antiques. Surprisingly, even after African independence, the definitions used by heritage laws remained unchanged. In fact, most of the heritage legislation of African countries still dates back to the 1960s and 1970s. ${ }^{73}$ Hence the conclusion by some scholars who suggest that heritage legislations and definitions reflect Eurocentric views of heritage that has traditionally valued monuments and sites over the intangible values associated with them. ${ }^{74}$

As a result, rarely was intangible heritage (also named living heritage) incorporated in the definition of heritage. If incorporated, the definitions often emphasised only certain aspects of intangible cultural heritage. Early expert definitions in the United Nations Educational Scientific and Cultural Organisation (UNESCO) focused on artistic creations like performance, but by the late 1990s, emphasis was also being placed on knowledge and values. ${ }^{75}$ The Human Science Research Council (HSRC), argued in their findings that definitions at a national level reflect national cultural and political concerns

71 First adopted at an Australian small town Burra in 1979; was put together by the Australian International Council on Monuments and Sites (ICOMAS) to identify the principles that should be used for conservation of Heritage Resources.

72 World Heritage Centre, http://whc.unesco.org/

73 Ndoro W. 2005. "Legal definitions of Heritage", in Ndoro W, Mumma A and Abungu G (eds). Cultural Heritage and the Law: Protecting Immovable Heritage in English Speaking Countries of Sub-Saharan Africa. Rome: ICCROM.

74 See, for instance, Ndoro, "Legal definitions of Heritage".

75 Human Sciences Research Council Report. 2004. Definitions of intangible heritage HSRC, 27. 
and that any national instruments which do not include oral histories in their definition of intangible heritage, such as the NHRA, is unusual in not including them. ${ }^{76} \mathrm{~A}$ further limitation, and more significant to the argument in this chapter, is that definitions of intangible heritage excludes expressions of religion and spirituality.

Like much legislation, the NHRA has its basis in the precedent of the previous National Monuments Act, which was revised to suit the new democratic dispensation. The NHRA set out to redress past inequalities and to promote the management of the national estate in a way that was necessary to define the nation's multi-cultural identity, as well as to promote nation-building. The urgent need to redress what Colette Scheermeyer, Head of South African Heritage Resources Agency, describes as "many years of neglect and disregard for the many facets of heritage and extensive cultural treasures associated with non-white communities", 77 may have compelled the NHRA to employ a broad conception of heritage. ${ }^{78}$

Following the recommendations of the Arts and Culture Task Group, intangible heritage was included as one of the resources that required protection. The NHRA describes living heritage as intangible aspects of inherited culture that may include "cultural tradition, oral history, performance, ritual, popular memory, skills and techniques, indigenous knowledge systems and the holistic approach to nature, society and social relationships" ${ }^{79}$

Janette Deacon recollects that when the NHRA was written, intangible heritage was difficult to legislate, because the UNESCO convention on intangible heritage had not been drafted at that time. ${ }^{80}$ Thus, there were no guidelines. On those grounds, intangible heritage is only discussed in the preamble. Janette Deacon concluded that, if the Heritage Act was to be re-written, the part on intangible heritage would be a priority - "be more specific" ${ }^{81}$

One of the limitations of the NHRA stems from its wide-ranging provisions. Although the NHRA incorporates different conceptions of heritage and acknowledges the value of such to those groups who were previously marginalised, such a fluid conceptualisation of heritage poses difficulty in

76 Human Sciences Research Council Report, 27.

77 Scheermeyer C. 2005. "A Changing and Challenging Landscape: Heritage Resources Management in South Africa", The South African Archaeological Bulletin 60(182): 121-123.

78 A heritage resource or national estate on the Act is defined as any place, building, landscape, geological, archaeological or paleontological sites and graves and burial grounds, as well as objects and records of cultural importance.

79 Indigenous beliefs about ancestors and cultural practices related to ancestors fall within intangible heritage, The National Heritage Resources Act 1999, section 2. Ancestral beliefs are recognised as indigenous knowledge systems.

80 Interview with Janette Deacon by D Skosana, Iziko Museum, July 2015.

81 Ibid. 
applying a legal framework. ${ }^{82}$ Zimbabwean heritage practitioner, Webber Ndoro argues that "definitions of heritage in legal instruments have to be very precise so as to avoid ambiguity. Precision leaves no doubt with regard to what falls within the coverage of the law." ${ }^{\prime 83}$ Webber Ndoro also highlights the importance of such precision when he points out that definitions have a direct impact on the scope of the national legislative instruments. They determine the regulation of powers, what is to be protected and how. ${ }^{84}$ Reflecting on heritage definitions in English-speaking sub-Saharan countries, Ndoro records that, except in South Africa, these countries have very narrow and specific definitions. ${ }^{85}$ His evaluation concludes that with narrow and specific definitions, the danger is always that much heritage - including intangible heritage, cultural landscapes, and itineraries - will not be covered. Broader definitions have an obvious advantage in being all-inclusive. However, they may suffer from lack of detail about the types of protected heritage. ${ }^{86}$ The lack of detail in the NHRA for instance, is evident in that ancestral beliefs are protected as "indigenous knowledge systems", without consideration of the contestations about this conceptualisation, who defines indigenous systems or how law should engage with indigenous knowledge systems. This permits any other party which seeks to relocate graves to neglect their importance to communities because their significance is not legally endorsed. The failure to thoroughly articulate the significance of graves and ancestors is partly due to the influence of Christianity in law making.

\section{IMPLEMENTATION OF NATIONAL HERITAGE RESOURCES ACT}

The Arts and Culture Department guidelines proposed a three-tier system for the management of heritage resources. This would be a decentralised administrative system in which the decision making was done by central authorities. Critiquing the three-tiered system, the University of the Witwatersrand archaeologist Amanda Esterhuysen writes that, "unfortunately, rather than presenting a strong and united conservation unit, the tiered heritage system tends to be undeveloped, under-resourced and uncoordinated." ${ }^{\prime 87}$ She further suggests that "communication between Heritage Departments, Agencies and Councils, the National Provincial and Municipal Departments of health,

82 Ndoro W and Pwiti G (eds). 2005. Legal frameworks for the Protection of immovable cultural Heritage in Africa, Rome: ICCROM.

83 Ibid.

84 Ibid.

85 Ibid.

86 Ibid.

87 Esterhuysen A. 2009. "Undermining Heritage”, The South African Archaeological Bulletin 64(189). 
environment, and planning, result to slow and questionable decision making." 88 Janette Deacon shared the same view when she said,

What is happening especially within mining, is that those departments are not working together with other departments. So, the mining people, the Department of Minerals ... are not interacting with the Department of Environmental Affairs for example. And they are not interacting with the Department of Arts and Culture. Ideally, they should be. But it's not happening. And because our constitution doesn't allow for one department to argue with another department, we are stuck in many ways.

The three-tiered system required a change of the Monuments Council, which had four regional branches for the four provinces that existed before 1994 . This meant that decisions about the significance of heritage places should ideally be taken at the lowest competent level of governance - in other words ideally at a local level, although it is not clear from the NHRA who constitutes local authorities. At the provincial level, NHRA would be implemented by the Provincial Heritage Resources Agencies PHAHs, except in cases where the South African Heritage Resources Agency (SAHRA), which serves as the national implementation body that manages the functions of NHRA, acts on behalf of the provinces. Heritage resources considered of provincial significance are managed by PRAHs and those regarded as of national significance are managed by SAHRA.

According to NHRA, all levels of authorities must coordinate the identification and management of the national estate that is graded from one to three. ${ }^{89}$ This grading system caused an outcry during consultations for the heritage bill. One of the major concerns was that when the bill was put into law, all previous monuments, which included a very large number of colonial buildings, became provincial heritage sites. So, it immediately reduced their significance to provincial level rather than national. Controversy was primarily from the owners of buildings who saw their property as being demoted..$^{90}$ Additionally, there was also less funding opportunity across provinces for the heritage resources graded under provincial heritage. According to Webber Ndoro and Donatius Kamamba, ${ }^{91}$ the ranking system is used by most countries in order to

88 Esterhuysen, "Undermining Heritage".

89 Grade I heritage resources are "those with qualities so exceptional that they are of special national significance", Grade II heritage resources are those "which, although forming part of the national estate, can be considered to have special qualities which make them significant within the context of a province or a region". Grade III heritage resources- are those of local significance and are administered by a local authority. The graves which were relocated by Glencore mine are classified under Grade III heritage resources, whereas, war graves or those of renowned political activists may be classified under grade I or II.

90 Interview with Janette Deacon.

91 Director of the Antiquities Division at the Ministry of Natural Resources and Tourism in Tanzania. 
establish priorities for management by heritage organisations. ${ }^{92}$ These authors also suggest that heritage ranking in other countries affects property rights and determines public access and management responsibilities of the state. In a ranking system, they argue, cultural heritage is more likely to suffer, because, in Africa, it is not manifested only through monuments. ${ }^{93}$

\section{THE PROTECTION OF GRAVES IN SOUTH AFRICA}

The above history of the NHRA is essential to understanding the legal regime governing the protection of graves in South Africa. Graves are protected and regulated under Section 36 of the NHRA. A grave is defined as "any place of interment, including its contents, headstone, or other markers of such a place, and any other structure on or associated with such a place". ${ }^{94}$ Graves are categorised according to the following two primary criteria: those inside and outside of a formal cemetery, and those graves that are younger and those older than 60 years. To exhume archaeological graves (older than 100 years old), those of victims of conflict, royal or traditional leaders; historical graves or burial grounds, and any grave or burial ground older than 60 years which is situated outside a formal cemetery administered by the local authority, a permit is obtained from SAHRA..$^{95}$ Graves that are less than 60 years old and inside a formal cemetery require permission from the Health Department and or a local municipality to relocate. There are no formalised guidelines for this application process, nor is there a definite understanding of what constitutes a local heritage authority. When asked about why there were classifications of graves by date, Janette Deacon explained that it was partly a carryover from the National Monuments Council, and a desire to separate things which would be defined as archaeological from those defined as historical. ${ }^{96}$ On this point, Deacon reasoned that "for archaeological things it is virtually impossible to trace the previous owners of that place so you have got to regard the archaeological things, written in the act as things that belong to the state, in other words not individually owned."

One of the key weaknesses of the NHRA, is that protection is only extended to graves over 60 years of age, graves of victims of conflict and those graves considered as of cultural significance. In essence, only graves that are over 60 years of age are treated as heritage resources. These are relocated in line with

92 Ndoro W and Kamamba D. 2005. “The Ranking of Heritage Resources and sites in Legislation", in Ndoro, Mumma and Abungu, Cultural Heritage and the Law, 40.

93 Ibid.

94 National Heritage Resources Act, 1999, Section 2.

95 Ibid.

96 Interview with Janette Deacon. 
SAHRA's guidelines. Explaining why graves that are 60 years old would be considered heritage resources, Deacon reflects that this is mainly because,

We felt that 60 years was a kind of cut-off point that you could have lost touch with where the graves of family members were. And would most likely have moved away and would not know about graves being exhumed for one reasons or another. And we felt that it was necessary to put that into law and we also assumed, maybe it was a wrong assumption in some ways, that by 60 years, local authorities would have been organised enough to have made a list of all people who were buried there and so that they would be able to pick up on the consultation process. I don't know if that was a good idea. It's hard to say.

Graves that are less than 60 years old, not of victims of conflict or of cultural significance, fall out of the NHRA and are therefore, regulated through the Human Tissue Act $65^{97}$ and municipal ordinances. These ordinances require an undertaker to remove the grave, although the NHRA does not make provisions for the process that needs to be followed by the local authorities to ensure that the employed undertaker has the necessary experience. On the contrary, graves over 60 years require a qualified archaeologist to remove. Archaeologists are required to conduct research on the grave, record the layout of the grave and objects found, as well as to consolidated into a report. This is a slower and more costly exercise as compared to hiring an undertaker who is also not required to be in possession of an exhuming license. Thus, developers often seek to find loopholes which can make it possible for the relocation to be carried out by the undertakers.

For any development, the developer is expected to contact SAHRA to inform the agency of the intended development. ${ }^{98}$ SAHRA then has an opportunity to consider if the development will affect any heritage and instruct the developer to submit a Heritage Impact Assessment. ${ }^{99}$ SAHRA can also instruct the developer to contact a provincial or local heritage authority if it decides the heritage should be administered on a provincial or local level. According to the Heritage Act, the permit should only be granted once SAHRA finds that adequate arrangements have been made for the process of alteration or relocation contemplated by the applicant. ${ }^{100}$ The latter is obligated to contact and consult with individuals and communities who may have an interest in the

97 In sum, the tissue act states that you may not store any human tissues anywhere other than at a medical facility. This was to prevent institutions such as museums from keeping human remains that have been fossilised and technically are no longer remains but turned into stone.

98 National Heritage Resources Act, 1999, Section 38 (5)(b).

99 Section 38 (2). The processes and implications of the Heritage Impact Assessment submissions will be discussed in detail in the next chapter which deals with the provisions of the Mineral and Petroleum Resources Development Act.

100 National Heritage Resources Act, 1999, Section 36. 
graves and thereafter, enter into an agreement with them. ${ }^{101}$ However, there is no definite framework for consultation with communities; as a result, there is no verification process in place to ensure that the person who gives permission to move the grave is the rightful member of the family.

Explaining the relocation process, South Africa heritage consultant from Professional Heritage Solutions, Henk Steyn, mentioned that meetings related to grave relocations are announced in local newspapers, in a language that communities understand. ${ }^{102}$ Families are often offered a "wake fee", which is intended to help prepare for the reburial ceremony. The mine fee covers expenses such as a coffin, transport costs and in other cases, compensates families for the relocation of the graves. Compensation creates family disputes, as members of the families do not always agree on what can be considered a reasonable compensation amount for the relocation of a grave. ${ }^{103}$ Wake fees and other forms of compensation are not legislated; as a result, both developers and communities are often at loggerheads.

\section{CONCLUSION}

This chapter demonstrates that external legal systems such as Roman law and Roman-Dutch law, both which have their basis in Christian values have had a great influence on South African legislation, in particular the National Heritage Resources Act. Continued adherence to international legislative standards sets the NHRA as the most progressive heritage legislations in Africa. In reality, however, the international typologies of heritage employed do not adequately provide for intangible heritage (non-Christian beliefs). This inadequacy permits the disturbance of graves because the relationship between ancestors and communities is not thoroughly provided in laws protecting graves. Grave disturbances in the brief highlighted case study, were carried out in manner that undermines the cultural rights of the previously disadvantaged peoples. One of the major contestation to emerge out of the case study, was that failure to compensate the disturbed graves made it impossible for the families to perform cultural rituals that provide spiritual security for the living members. Overall, the chapter highlighted that provisions for intangible heritage or beliefs related to ancestors require further development.

101 National Heritage Resources Act, 1999, Section 36 (5)(a).

102 Interview with Henk Steyn by D Skosana, 30 October 2014.

103 Interview with Henk Steyn. 